3. Egorov, V. V., Skibickij, E. G., \& Hrapchenkov, V. G. (2008). Pedagogika vysshej shkoly: Uchebnoe posobie [Higher Education Pedagogy: Study Guide]. Novosibirsk: SAFBD. (in Russian)

4. Knigavko, V. G. (ed.) (2017). Biological, medical and physiological cybernetics. Medical information science: textbook for 2nd year students of medical universities. Kharkiv: KhNMU, pp. 74-82.

\title{
IMPACT OF VOLONTEERING ON FUTURE PE TEACHERS’ PATRIOTIC EDUCATION
}

\section{Inna Kurlishchuk ${ }^{1}$ Yurii Poluliashchenko ${ }^{2}$}

DOI: https://doi.org/10.30525/978-9934-588-39-6-10

Throughout the history of Ukraine, the system of Higher Education has been called upon to shape patriotic education of university student youth, in particular to form and share social knowledge, political, civic and moral attitudes towards different community and state problems; to improve citizen's pro-social behavior and civic mindedness; to foster personal tollerance and understanding the cultural differences among members of Ukrainian society that are belong to multivariately viewed social groups as well as to support community cohesion. Under modern social and political conditions in our country that are characterized by the strong focus on European integration and values, the problem of preserving national identity, the uniqueness of Ukrainian historical and cultural heritage by the means of patriotic education of university student youth becomes relevant.

Today one of the most important problems of the system of Ukrainian Higher Education is the improvement of context and modernization of professional training of teachers and, especially future PE teachers who have the greatest influence on spiritual and physical health of a new patriotic oriented generation of Ukrainians. The problem of patriotism formation of future PE teachers required further comprehensive study.

In pedagogical, psychological and social theory and practice a considerable number of researches on the issue of university students' patriotic education have been conducted (I. Bekh, M. Boryshevskyi, K. Chorna, L. Chuprii, O. Savchenko, M. Yevtukh, O. Zharovska, K. Zhurba,

\footnotetext{
${ }^{1}$ Luhansk Taras Shevchenko National University, Ukraine

${ }^{2}$ Luhansk Taras Shevchenko National University, Ukraine
} 
I. Ziaziun and others), and in particular, future physical training teachers' patriotic education (O. Blokhin, V. Kindrat, A. Leonenko, Yu. Poluliashchenko, V. Saienko, H. Tolchieva, etc.). The phenomena of university student volunteering was the subject of researches of such scholars as E. Balashov, Z. Bondarenko, O. Karaman, S. Kharchenko, A. Kolomiets, I. Kozubovska, T. Lyakh, I. Petrenko, T. Rudiakevych and more. Nevertheless, the impact of volunteering on future PE teachers' patriotic education is not yet defined as well.

Therefore, the purpose of the article is to examine the influence of volunteering on future physical training teachers' patriotic education.

Summarizing the opinions of a number of scholars (O. Kolodii [2], S. Magaril [4], H. Takeuchi et al. [7]) noticed that patriotism can be regarded as love for a country, devotion to the state expressed in knowledge of achievements of the country, acceptance of spiritual and moral society values and traditions, readiness to work for stability and prosperity of the country, and overall responsibility for social behavior and attitudes towards the main state's challenges. In this context patriotism is defined as a deeply social phenomenon in nature. It is an essential aspect of society's life as well as a source of its existence. It is obvious that successful society development depends on patriotism of people making it. V. Kulchytskyi and M. Sopiha emphasized that "patriotism is one of the most significant eternal values inherent in all spheres of society and state. It is the most important spiritual heritage of personality, characterizes the higher level of their development and manifests itself in their active self-realization for the benefit of the Motherland» [3, p. 59].

Analysis of the legal state documents [5] shows that patriotic education of modern Ukrainian generation is oriented on a higher level of their national, spiritual, ethical, moral, cultural development as well as a person integration into a social life and a willingness formation to devote themselves for the state building.

We consider that volunteer activities have a significant impact on upbringing of the present patriots among university student youth. Often volunteering is considered in terms of socially active and beneficial behavior for the sake of state. It is seen as a means of individual personal developing, socializing, and gaining new social knowledge and skills. Civic activity is manifested in various volunteering political and social projects, and, in the end, contributes to patriotism formation among wide sections of university student youth.

Nowadays a lot of modern researches of Ukrainian political scientists, sociologists and educators describe university student youth as a progressive social group that is deeply interested in politics, economics and social spheres. Moreover, most of them are actively engaged in work of different civic, political, social organizations, in particular throughout the volunteering. 
Adhering to position of Randall Curren and Charles Dorn [6] as well as Clare Holdsworth and Georgina Brewis [1] treats the student youth voluntering as an essential part of social life and a resource of better understanding of the patterns of political, economical, cultural and social environment, and thus as an effective means of youth patriotic education.

The paper focuses on problem of patriotic education of university students spesialized in physical education in Institute of Physical Education and Sports of Lugansk Taras Shevchenko National University. The empirical research finds out students' attitude and awareness to volunteering, discover their motivation, determines the main directions of their activities as volunteers, systematizes the information about the projects in which they participated as volunteers, studies benefits and problems of student volunteer work. The sample of the study consisted of 87 students. The student participants were at different stages of their studies: 27 of them had been studying for 4 years; 34 of them were the third- year students whereas the remainder (26) was the second- year - students. The median age of the respondents was 19, 5 years old. Approximately $64,4 \%$ of the respondents were male. The empirical research was conducted during 2017 - 2019 years.

According to the results of empirical research, the volunteer activity of students of Institute of Physical Education and Sports of Lugansk Taras Shevchenko National University was defined as constant, dynamic and diverse. During the research period students of the specialty Physical Education took part as sports volunteers in organizing and holding a number of local and regional patriotic sports events. They also carried out large-scale local tourist activities on the territory of Luhansk region as well as conducted environmental protected companies. Students were active participants in annual university and local sports competitions, in particular, the Feast of the Intercession, Go girls, go!, Go boys, go!, Cossack Fun, etc. Most students had experience in voluntary work for Ukrainian Armed Forces. Our research showed that only $17,2 \%(n=15)$ respondents had volunteer experience before university entry and 70,1\% $(\mathrm{n}=61)$ respondents are current volunteers. 77,04\% $(n=47)$ respondents with volunteer experience said that they do volunteer work on their own decision. The most preferable area of volunteering to students is voluntary work in Ukrainian Armed Forces, sports clubs and health services. This information is presented in Figure 1 (it was possible to give several answers (up to 3)).

The main students' motivation for volunteering were altruistic, educationrelated and social motives. This information is shown in Figure 2 (it was possible to give several answers (up to 3)). 


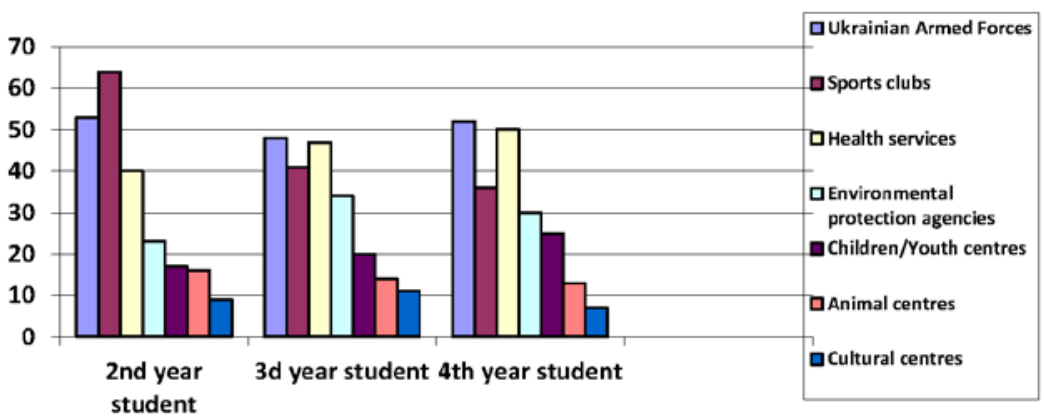

Figure 1. Preferable area of volunteering
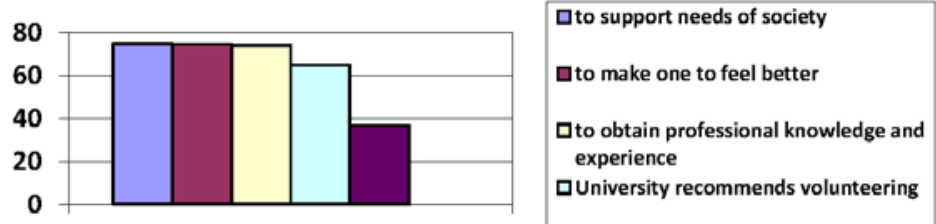

Figure 2. Students' motivation to volunteer activities

Conclusions. Thus, volunteer activity has received wide dissemination among university students spesialized in physical education in Institute of Physical Education and Sports of Lugansk Taras Shevchenko National University. Most respondents answered that their volunteer work is related to their future profession. A number of respondents defined on personal, civic and social benefits of volunteer activities. Student volunteering is oriented on comprehensive development of a person: civic, social, cultural, moral and spiritual, psychological, professional and personal, etc. It is noted that modern system of work on university students' patriotic education is based on volunteer activities.

\section{References:}

1. Holdsworth, C., \& Brewis, G. (2014). Volunteering, choice and control: A case study of higher education student volunteering. Journal of Youth Studies, vol. 17, no. 2, pp. 204-219.

2. Kolodii, O. S. (2010). Poniatiina struktura katehorii «patriotyzm» [Conceptual structure of the category «patriotism»]. Visnyk Zhytomyrskoho derzhavnoho universytetu imeni I. Franka [Bulletin of Zhytomyr State University named after I. Franko], no. 49, pp. 71-75. (in Ukrainian)

3. Kulchytskyi, V., \& Sopiha M. (2018). Patriotism as the social value of the individual. Social Work and Education, vol. 5, no. 3, pp. 57-64. 
4. Magaril, S. A. (2016). Smysly patriotizma - istoricheskie transformacii [Meanings of patriotism - historical transformation]. Sotsiologicheskie issledovaniya [Sociological Studies], no 1, pp. 142-151. (in Russian)

5. Natsionalno-patriotychne vykhovannia ditei ta molodi. Normatyvna baza [National and patriotic education of children and youth. Legal basis] (2020). URL: https://imzo.gov.ua/osvita/pozashkilna-osvita-ta-vihovna-robota/natsionalnopatriotichne-vihovannya-ditey-ta-molodi/ (in Ukrainian)

6. Randall Curren, R., \& Dorn, Ch. (2018). Patriotic Education in a Global Age. Chicago, IL: University of Chicago Press.

7. Takeuchi, H. et al. (2016). Differences in gray matter structure correlated to nationalism and patriotism. Scientific reports. URL: https://www.nature.com/articles/ srep29912

\section{COMMERCIAL SEXUAL EXPLOITATION OF CHILDREN: INTERNATIONAL LEGAL ASPECTS}

\section{Victoria Melnychuk ${ }^{1}$}

DOI: https://doi.org/10.30525/978-9934-588-39-6-11

Commercial sexual exploitation of children is a serious crime against a child. The problem of commercial sexual exploitation of children is complex and needs to be addressed globally. Today, there are already a number of international instruments regulating the law on crimes related to the commercial sexual exploitation of children. These are, first and foremost, the documents of the United Nations, the Council of Europe, as well as bilateral and multilateral agreements between states, which, by ratifying these agreements, legally undertake to comply with the conditions set out in them.

The issues of legal protection of children who became victims of commercial sexual exploitation were investigated by M. Buryak, A. Vozniuk, I. Dolyanovskaya, M. Kovaleva, L. Kovalchuk, K. Levchenko, Y. Nagachevska, N. Plahotniuk, Y. Smirnov, O. Swed and others.

Commercial Sexual Exploitation of Children (CSEC) is a serious violation of the rights of the child, considered as sex and trafficking; and includes sexual abuse of a child or the exploitation of a child by an adult, as well as payment of cash or in kind to a child or a third party / persons [2, p. 414]. Commercial sexual exploitation of children includes child prostitution,

\footnotetext{
${ }^{1}$ State Scientific Institution «Institute for the Modernization of the Content of Education», Ukraine
} 